\title{
Arkadiusz Sieroń
}

University of Wroclaw

e-mail: sieron.arkadiusz@gmail.com

ORCID: 0000-0002-5817-8747

\section{LEGACY OF MENGER'S THEORY OF SOCIAL INSTITUTIONS}

\begin{abstract}
The aim of the article is to examine the legacy of Menger's theory of social institutions. We argue that Menger's insights about the origin of social structures inspired later contributions in three main areas: theory of spontaneous order, theory of money, and theory of law.

Keywords: Carl Menger, theory of social institutions, spontaneous order, theory of money, theory of law
\end{abstract}

\section{Introduction}

Carl Menger was born in 1840 in Galicia, then part of the AustroHungarian Empire, but now southern Poland, and died in 1921 in Vienna. In 1871, he published Principles of Economics, which made him a founder of the Austrian school of economics and a co-founder of the marginal utility revolution ${ }^{1}$. Indeed, his major contributions are the theory of value and price, which revolutionized economics. Menger is also famous for his engagement in the methodological debate (Methodenstreit) with the representatives of the German Historical School. As a result of his methodological research, Menger published Investigations into the Method of the Social Sciences with Special Reference to Economics in 1883. Last but not least, Menger developed an organic theory of social institutions, which is, according to Huerta de Soto (2006), perhaps Menger's most important contribution. Although he focused on money in his writings - in 1892 his pathbreaking essay "On the Origins of Money" appeared in the Economic Journal - Menger extended his analysis to other institutions, such as language or law. ${ }^{2}$

The aim of this article is to examine Menger's theory of social institutions and its legacy. We focus on three fields: theory of spontaneous order, monetary theory, and legal theory. The remainder of the paper is, thus, 


\section{Arkadiusz Sieroń}

organized as follows. Section II presents briefly Menger's theory of social institutions. Next, I analyze later developments of that approach applied to Friedrich Hayek's theory of spontaneous order (section III); monetary theory and Mises' contribution to it (section IV); and Bruno Leoni's legal theory (section V). Section VI concludes.

\section{Menger's Theory of Social Institutions}

Menger (1883 [1985) divides social phenomena into two groups according to their origin. The first group is the result of a common will directed toward their establishment, while the second is the unintended result of human efforts pursuing individual goals and interests.

The characteristic element in the socially teleological genesis of social phenomena is in the intention of society as such directed toward establishing these phenomena, under the circumstance that they are the intended result of the common will of society, thought of as an acting subject, or of its rulers. The social phenomena of "organic" origin, on the other hand, are characterized by the fact that they present themselves to us as the unintended result of individual efforts of members of society, i.e., of efforts in pursuit of individual interests. Accordingly, in contrast to the previously characterized social structures, they are, to be sure, the unintended social result of individually teleological factors. (Menger, 1883 [1985], 158)

The former category includes the agreement of members, legislation, etc., while the latter group consists of many social institutions, such as language, money, law, or markets, and many other phenomena, social in general and economic in particular.

Law, language, the state, money, markets, all these social structures in their various empirical forms and in their constant change are to no small extent the unintended result of social development. The prices of goods, interest rates, ground rents, wages, and a thousand other phenomena of social life in general and of economy in particular exhibit exactly the same peculiarity. (Menger, $1883[1985], 147)^{3}$

According to Menger, the emergence of such institutions is probably the most important problem of social sciences. He went even so far to argue that:

The solution of the most important problems of the theoretical social sciences in general and of theoretical economics in particular is thus closely connected 
with the question of theoretically understanding the origin and change of 'organically' created social structures (Menger, 1883 [1985], 197).

Hence, the central question which social researchers (especially economists) must answer, according to Menger, is thus as follows:

How can it be that institutions which serve the common welfare and are extremely significant for its development come into being without a common will directed toward establishing them? (Menger, 1883 [1985], 146, emphasis original)

Menger's answer is that the pursuit of economic interest by individuals generates orderly outcomes leading to social benefits, though unintentionally. Since his theory of the origin of money - examined in more detail in section 4 - is the best example of Menger's spontaneous-order explanation, it deserves a brief review. As goods differ in their marketability, some people who wish to trade, facing all the problems connected with the barter economy, will start at some point to exchange their less marketable goods for more marketable goods, even if they do not need them directly, since it brings them closer to their goals. In other words, individuals eventually realize that acquiring goods that other people desire (accept in trade) is the best way to achieve their individual objectives.

The economic interest of the economic individuals, therefore, with increased knowledge of their individual interests, without any agreement, without legislative compulsion, even without any consideration of public interest, leads them to turn over their wares for more marketable ones, even if they do not need the latter for their immediate consumer needs. Among the latter, however, as is readily evident, they again select those which are most easily and most economically suited to the function of a means of barter. Thus there appears before us under the powerful influence of custom the phenomenon to be observed everywhere with advancing economic culture that a certain number of goods are accepted in exchange by everybody. (Menger, (1883 [1985], 154, emphasis original)

Clearly, Menger's approach echoes Smith's concept of an invisible hand, which is not surprising, as the notion of spontaneous order was hardly new in Menger's time ${ }^{4}$. It was developed by a group of thinkers associated with the Scottish Enlightenment - and Smith's metaphor of an invisible hand has become the most common representation of that ideas (Smith, 1776). However, Menger "convincingly incorporated the notion of spontaneous order into the system of theoretical economics" (Penchev, 2014, 731). 


\section{Menger's Legacy in the Theory of Spontaneous Order}

The legacy of Menger's pioneering analysis of the evolution of social institutions is multi-faceted. I will analyze his contributions to the monetary and legal theory in further sections. Here, I would like to point out that Merger's focus on the 'organically' created social structures, including money and law, without a centralized decision anticipated the fully developed examination of private property, the freely fluctuating money prices and economic calculation found in Mises (1920) and Hayek (1945). Indeed, particularly the latter focused on the analysis of undersigned social institutions. ${ }^{5}$ Actually, the issue how social institutions coordinate individuals' plans and actions was the common theme in Hayek's writings (Boettke, 1990). The 1974 Nobel Prize Laureate in Economics offered a few important insights to Menger's contributions in that matter.

First, he extended Menger's methodological remarks about the scope of social science. Menger believed that the evolution of 'organic' institutions was the main subject of research. Similarly, for Hayek, the very need of theoretical social studies arises from the fact that there is a social order which emerges by human action but not human design:

If social phenomena showed no order except in so far as they were consciously designed, there would indeed be no room for theoretical sciences of society and there would be, as is often argued, only problems of psychology. It is only in so far as some sort of order arises as a result of individual action but without being designed by any individual that a problem is raised which demands a theoretical explanation (Hayek, 1952, 69).

Second, he pointed out the "the epistemic limits to humanity's ability to design and direct our institutions and their outcomes consciously" (Horwitz, 2001, 86). These limits result from the "the fact that the knowledge of the circumstances of which we must make use never exists in a concentrated or integrated form but solely as the dispersed bits of incomplete and frequently contradictory knowledge which all the separate individuals possess" (Hayek, 1945, 77). Much of the needed knowledge is also tacit or contextual. Hence, the relevant knowledge cannot be centralized and used in a human design.

Third, Hayek considered market exchanges and the resulting prices as a form of communication which enables individuals to coordinate their plans. By emphasizing the signal function of prices, Hayek showed that institutions not only can emerge as an unintended result but that they can contribute themselves to the larger spontaneous order of society. The market 
through price mechanism and the system of profit and loss enables economic calculation and coordination of individual actions, leading to the effective allocation of resources.

\section{Menger's Legacy in Monetary Theory}

The most widely known example of Menger's theory of the 'organic' emergence of social institutions is his explanation of the origin of money. Menger $(1871 ; 1883 ; 1892)$ argues that it was not the top-down result of an act of will, but the unplanned product of market mechanisms.

Menger (1892, [2009]) complains about the lack of a satisfactory theory of money. The very aim of his writing on the origin of money was to reject the explanation of the specific function of money as a universal current medium of exchange referring to a general convention or a legal dispensation. ${ }^{6}$ This is why he develops the concept of spontaneous or 'organic' genesis of money as the only suitable approach to such analysis:

It is not impossible for media of exchange, serving as they do the commonweal in the most emphatic sense of the word, to be instituted also by way of legislation, like other social institutions. But this is neither the only, nor the primary mode in which money has taken its origin. This is much more to be traced in the process depicted above, notwithstanding the nature of that process would be but very incompletely explained if we were to call it "organic" or denote money as something "primordial," or "primaeval growth," and so forth. Putting aside assumptions which are historically unsound, we can only come fully to understand the origin of money by learning to view the establishment of the social procedure, with which we are dealing, as the spontaneous outcome, the unpremeditated resultant, of particular, individual efforts of the members of a society, who have little by little worked their way to a discrimination of the different degrees of saleableness in commodities. (Menger, $1892[2009], 38)^{7}$

Menger (1871 [2007]; 1892 [2009]) begins his analysis assuming a barter economy. He then points to the difficulties that exist in the system of direct exchange, particularly to the fact that for barter to occur, both parties need to have what the other wants ("double coincidence of wants"). And because goods have different degrees of marketability (for example, in the Homeric age, cattle was more saleable that armor), economizing individuals will be inclined to exchange their products not only for those goods that they desire to consume directly, but also for more marketable goods, as the possession of goods with high marketability improves their chances to acquire what 


\section{Arkadiusz Sieroń}

they really want (for example, a smith would be pleased by exchanging his armor for cattle, even if he wants to consume fish, as possession of these more saleable goods facilitate his search for people offering the very goods he needs). As more and more people start to accept these goods in their exchanges, their marketability rises even further. This gradual, self-reinforcing process eventually leads to the selection of the common medium of exchange (or perhaps a few media), i.e. money, although nobody intended it.

In a famous passage, Menger (1871 [2007], 260, emphasis original) writes:

As each economizing individual becomes increasingly more aware of his economic interest, he is led by this interest, without any agreement, without legislative compulsion, and even without regard to the public interest, to give his commodities in exchange for other, more saleable, commodities, even if he does not need them for any immediate consumption purpose. With economic progress, therefore, we can everywhere observe the phenomenon of a certain number of goods, especially those that are most easily saleable at a given time and place, becoming, under the powerful influence of custom, acceptable to everyone in trade, and thus capable of being given in exchange for any other commodity. 8

There are three key points in Menger's writings on money. First, he introduced the concept of the different degrees of marketability of commodities as the basis for the understanding of the functions of money:

The difference existing in this respect between articles of commerce is of the highest degree of significance for the theory of money, and of the market in general. And the failure to turn it adequately to account in explaining the phenomena of trade, constitutes not only as such a lamentable breach in our science, but also one of the essential causes of the backward state of monetary theory. The theory of money necessarily presupposes a theory of the saleableness of goods. If we grasp this, we shall be able to understand how the almost unlimited saleableness of money is only a special case, - presenting only a difference of degree - of a generic phenomenon of economic life namely, the difference in the saleableness of commodities in general. (Menger, 1892 [2009] 20-12)

Second, the emergence of money is only a gradual, evolutionary process which needs time and 'learning by doing'. Hence, Menger was fully aware of the lack of perfect information among market participants, and that an unfettered market plays a crucial role in the dissemination of knowledge in society: 
It lies in the economic interest of each trafficking individual to exchange less saleable for more saleable commodities. But the willing acceptance of the medium of exchange presupposes already a knowledge of these interests on the part of those economic subjects who are expected to accept in exchange for their wares a commodity which in and by itself is perhaps entirely useless to them. It is certain that this knowledge never arises in every part of a nation at the same time. It is only in the first instance a limited number of economic subjects who will recognize the advantage in such procedure, an advantage which, in and by itself, is independent of the general recognition of a commodity as a medium of exchange, inasmuch as such an exchange, always and under all circumstances, brings the economic unit a good deal nearer to his goal, to the acquisition of useful things of which he really stands in need. But it is admitted, that there is no better method of enlightening any one about his economic interests than that he perceive the economic success of those who use the right means to secure their own. Hence it is also clear that nothing may have been so favourable to the genesis of a medium of exchange as the acceptance, on the part of the most discerning and capable economic subjects, for their own economic gain, and over a considerable period of time, of eminently saleable goods in preference to all others. In this way practice and habit have certainly contributed not a little to cause goods, which were most saleable at any time, to be accepted not only by many, but finally by all, economic subjects in exchange for their less saleable goods; and not only so, but to be accepted from the first with the intention of exchanging them away again. (Menger, 1892 [2009], 36-37) ${ }^{9}$

The third point is in a sense a consequence of the former: the emergence of money results not from state decree or convention, but from the selfinterested actions of individuals who wanted to improve their position by indirect exchange. Menger (1871 [2007], 262) firmly states:

Money is not the product of an agreement on the part of economizing men nor the product of legislative acts. No one invented it. As economizing individuals in social situations became increasingly aware of their economic interest, they everywhere attained the simple knowledge that surrendering less saleable commodities for others of greater saleability brings them substantially closer to the attainment of their specific economic purposes. Thus, with the progressive development of social economy, money came to exist in numerous centers of civilization independently.

Hence, Menger provided an irrefutable praxeological theory of the origin of money (Mises, 1949 [1998]), laying foundations for the developments of monetary theory. He "solved the problem of the evolution of a common medium of exchange" (O'Driscoll, 1985, 16), developing an evolutionary theory of money. His explanation inspired not only economists but also sociologists such as Simmel (2004), and became eventually the mainstream 


\section{Arkadiusz Sieroń}

theory of the origin of money. Menger's insights also enabled later Mises (1912 [1953]) to integrate monetary sphere into the subjectivist value theory. ${ }^{10}$ Using Menger's theory as a starting point, Mises formulated his regression theorem, according to which today's value of money is based on yesterday's purchasing power, and this causal chain of reasoning goes back to the point just prior to when a given commodity first started being used as a medium of exchange. Menger demonstrated that money itself originates from the market and, based on that insight, Mises (1912 [1953], 121) showed that the value of money can be traced back to "where the value of money is nothing other than the value of an object that is useful in some other way than as money." In that way, thanks to Menger's earlier works, Mises demonstrated that the general theory of subjective value and marginal utility may be also applied to money. ${ }^{11}$ At the end, I have to notice that not only Mises, but also other economists adopted Menger's approach to the monetary sphere - White (1984) and Selgin (1988) are probably the best examples of analyses of 'organic' evolution of banking. More recently, the emergence of cryptocurrencies is an interesting example of spontaneous order. Although they were created by the will of certain individuals, their acceptance as media of exchange occurred organically, without - or even despite - central authorities' actions and regulations. ${ }^{12}$

\section{Menger's Legacy in Legal Theory}

Menger (1883 [1985]) in the appendix argues that there are important 'organic' elements in the development of law as well. Although he has some reservations about the spontaneous emergence of law, Menger (1883 [1985], 227-33) notes:

National law in its most original form is thus, to be sure, not the result of a contract or of reflection aiming at the assurance of the common welfare. Nor is it, indeed, given with the nation, as the historical school asserts. Rather, it is older than the appearance of the latter. Indeed, it is one of the strongest ties by which the population of a territory becomes a nation and achieves state organization. (...) Common law is, indeed, not the intended result of the common will aimed at the common good but, as we have seen, an outcome of individual human efforts, and thus not in direct contrast to human wisdom.

However, jurisprudence has been for years resistant to Menger's insights about the nature of social science. According to Hayek $(1969,101)$ the reason for such an unfortunate state of affairs was that "the philosophy dominant 
in this field, legal positivism, still clings to the essentially anthropomorphic view which regards all rules of justice as the product of deliberate invention or design." 13 This is because the mechanism of evolution for a legal order is much less obvious than in the case of market order and its price system (Benson, 1989), despite the fact that "law evolved as an institutional input to coordinate the actions of individuals more effectively" (Boettke, Candela, 2014, 126).

But Leoni (1991) offered perhaps the most sophisticated 'organic' theory of law. According to Huerta de Soto $(2006,22)$, he was the first to incorporate Menger's theory of social institutions "in a synoptic theory on the philosophy of law: the economic theory of social processes developed by Menger and the Austrian school, the most time-honored Roman legal tradition, and the Anglo-Saxon tradition of rule of law."

Leoni first notices that "the very idea that the law might not be identical with legislation seems odd both to students of law and to layman" and then contrasts law-making by legislatures with a common law-like process described as "judicial decisions, the settlement of disputes by private arbiters, conventions, customs, and similar kinds of spontaneous adjustments on the part of individuals" (Leoni, 1991, 11). For him, the latter process was possible either thanks to the accumulated decisions of jurisconsults in ancient Rome or judges under English common law. Such law is thus a spontaneous order, as the law does not emerge as legislation, i.e. a written expression of the will of the winning majority in the legislative assembly, but as a byproduct of individuals' efforts to protect their rights. In other words, law originates in the market for judicial settlement of disputes between private parties, as a result of judges' resolutions. As Leoni puts it,

It means that the whole process can be described as a sort of vast, continuous, and chiefly spontaneous collaboration between the judges and the judged in order to discover what the people's will is in a series of definite instances a collaboration that in many respects may be compared to that existing among all the participants in a free market. (Leoni 1991, 16).

As one can see, Leoni considers common law as Mengerian 'organically' created social structures analogous to language or market process. The common law rules and judges' verdicts, as market prices, feedback into individual's decision-making, enabling people to coordinate their actions. ${ }^{14}$ The judges are seen either as a grammarian who just epitomizes the rules or as a sort of entrepreneur who proposes different rules trying to discover the most just resolution through the procedure of trial and error (Zywicki, 2014). 
On that basis, Leoni (1991) describes important features of common law. First, as law is not the product of the state's will, but the result of the interaction between judges and judged, or the consequence of the mutual consent of parties entering into reciprocal arrangements, he considers law as something to be discovered (or found), not something to be made:

Both the Romans and English shared the idea that the law is something to be discovered more than to be enacted and that nobody is so powerful in his society as to be in a position to identify his own will with the law of the land. (Leoni, 1991, 15, emphasis original)

Second, particular resolutions apply only to interested parties. As the legal process traces back ultimately to individual claims, judges or lawyers intervene only when directly asked by parties of the dispute - and their decisions apply only to the people concerned.

Third, the legal decisions usually refer to previous verdicts in similar cases. The judges are not mechanically bound by prior settlements, but they exert significant influence, which should not be surprising as when law is considered as being discovered, it makes perfect sense to refer to rules already found earlier. Hence, there is provided a continuity and stable institutional framework which increases certainty among the citizens. As Leoni (1991, 22) writes,

First, judges or lawyers or others in a similar position are to intervene only when they are asked to do so by the people concerned, and their decision is to be reached and become effective, at least in civil matters, only through a continuous collaboration of the parties themselves and within its limits. Second, the decision of judges is to be effective mainly in regard to the parties to the dispute, only occasionally in regard to third persons, and practically never in regard to people who have no connection with the parties concerned. Third, such decisions on the part of judges and lawyers are very rarely to be reached without reference to the decisions of other judges and lawyers in similar cases and are therefore to be in indirect collaboration with all other parties concerned, both past and present. ${ }^{15}$

In contrast, legislation is enforced upon everybody, whether they are in dispute or not. Moreover, it is usually triggered not by individuals seeking help in a conflict through voluntary interaction, but - without being requested by anyone (except rent-seeking lobbyists) - by the state possessing a coercive monopoly of power, which enables it to impose an arbitrary new state of legal affairs.

Hence, Leoni contracts the short-run and long-run certainty of the law. The former is embodied in legislation and refers to the certainty resulting 
from the written formula - everyone knows the rules in advance, while in common law people have to wait until judgement 'discovers' them. Meanwhile, the latter is a feature of the common law and results from the fact that law in that legal system is not subjected to sudden and unpredictable changes according to the whims of legislatures. The law is not submitted to the arbitrary will of a legislative assembly - instead, judges settle disputes in reference to previous verdicts through cumulative and gradual refinements. He writes:

While legislation is almost always certain, that is, precise and recognizable, as long as it is 'in force,' people can never be certain that the legislation in force today will be enforced tomorrow or even tomorrow morning. The legislationcentered legal system, while involving the possibility that other people (the legislators) may interfere with our interactions every day, also involves the possibility that they may change their way of interfering every day. As a result, people are prevented not only from freely deciding what to do, but from foreseeing the legal effects of their daily behavior. (Leoni, 1991, 13, emphasis original $)^{16}$

The inherent uncertainty of the legislation is one of the reasons why Leoni believes that it is incompatible with freedom. This is because stable legal framework is necessary for people to plan and calculate, and for the free market to work effectively. Indeed, it seems that the very intense process of modern law-making is one of the reasons behind the so-called regime uncertainty in many countries, which hampers investments and economic growth (Higgs, 1997). Hence, Leoni $(1991,17)$ concludes:

There is more than an analogy between the market economy and a judiciary or lawyers' law, just as there is much more than an analogy between a planned economy and legislation. If one considers that the market economy was most successful both in Rome and in the Anglo-Saxon countries within the framework of, respectively, a lawyers' and a judiciary law, the conclusion seems to be reasonable that this was not a mere coincidence. ${ }^{17}$

Indeed, there is more than an analogy, since "legislation and central planning are really the same thing: coercively-backed commands emanating from the government that order individuals to act in certain ways that the government prefers" (Kinsella, 1995, 158-59). According to Leoni, Mises's arguments about the impossibility of rational economic planning under socialism can be extended to the legal sphere. This is because legislators, similarly to central planners, lack needed knowledge to enact appropriate rules taking into account the actual situation of citizens. ${ }^{18}$ He writes: 
No legislator would be able to establish by himself, without some kind of continuous collaboration on the part of all the people concerned, the rules governing the actual behavior of everybody in the endless relationships that each has with everybody else. No public opinion polls, no referenda, no consultations would really put the legislators in a position to determine these rules, any more than a similar procedure could put the directors of a planned economy in a position to discover the total demand and supply of all commodities and services. (Leoni, 1991, 20, emphasis original)

Because of that information problem law cannot be imposed top-down on society, but it must evolve bottom up, just like price structure, through the application of already discovered rules to new cases (Kinsella, 1995). In other words, "just as economic discovery requires the competitive process of the market to provide information and feedback to correct errors, competition in the provision of legal services is essential to the judicial discovery in law" (Stringham and Zywicki, 2011, 2). Competition in the law would not only solve, or mitigate at least, the problem of knowledge, but also the problem of judges' accountability or of rent-seeking behavior.

The work of Leoni inspired other scholars to recognize the evolutionary nature of law. ${ }^{19}$ The most renowned of them was Hayek, who also strongly opposed the idea of legal positivism, according to which all law is derived from the will of a legislator (legislation is the only source of law). ${ }^{20}$ For Hayek (1969, 102-103),

The whole conception, however, that law is only what a legislator has willed and that the existence of law presupposes a previous articulation of the will of a legislator is both factually false and cannot even be consistently put into practice. Law is not only much older than legislation or even the organized state: the whole authority of the legislator and of the state derives from preexisting conceptions of justice, and no system of articulated law can be applied except within a framework of generally recognized but often unarticulated rules of justice. (...) The whole of this positivist conception of law derives from that factually untrue anthropomorphic interpretation of grown institutions as the product of design which we owe to constructivist rationalism" (...) Law is never wholly the product of design but is judged and tested within a framework of rules of justice which nobody has invented and which guided people's thinking and actions even before those rules were ever expressed in words.

In a later publication on law, legislation, and liberty, Hayek $(1998,85)$ even argued that England owed its remarkable freedom thanks to the fact that "the law that governed the decisions of the courts was the common law, a law existing independently of anyone's will and at the same time binding upon and developed by the independent courts." 
Benson $(1989 ; 2011)$ follows Menger's workings on the origin of social institutions and argues that commerce and commercial law have developed organically without the aid of, or even despite, state regulation and legislation. He demonstrates that the Law Merchant was customary and was voluntarily produced and adjudicated by merchants, through the process of trial and error. It was developed "directly from the market exchange process as business practice and custom evolves" and it "facilitates interaction and makes exchange more efficient" (Benson, 1989, 645)

\section{Conclusions}

The idea of spontaneous order invented originally by Scottish thinkers was picked up and developed by Menger. Although he is most famous as a father of the Austrian school in economics and the co-founder of the marginal utility revolution, Menger also created a theory of the origin of social institutions. His contributions in this field are relatively unknown. It's an unfortunate state of affairs, since the idea of 'organically' created social structures inspired many social scientists after him, proving that it is a living research paradigm. Menger's legacy includes Hayek's works on spontaneous order, Mises's theory of money, and Leoni's ideas on law and legislation.

\section{N O T E S}

1 Although the triumvirate of Menger, Jevons and Walras paved the way for modern microeconomic theory, there are essential differences between them (Jaffe, 1976; Machaj, 2015).

2 On the life and work of Carl Menger, see: Hayek (1976 [2007); Salerno (2000).

3 Menger (1883 [1985]) also includes the development of new localities, religion, morals, the division of labor, markets, competition, speculative profits, etc. And the Public Choice theory of politics would say that government's actions are also 'organic' to some extent.

4 On the tradition of spontaneous order, see: Barry (1982).

5 See, for example, Hayek $(1969 ; 1998)$. The idea that the aim of social studies is to explain the unintended results of individual's actions pursuing their interests was also adopted by Popper, Nagel or Merton (Hayek, 1969).

${ }^{6}$ He basically wanted to answer the question "how certain items turn into goods which are accepted by everyone in exchange for the goods offered for sale to him, even when he has no need for them" (Menger, 1883 [1985], 153). Menger believed that this very paradox prompted scholars to adopt a view that money was the result of some social agreement or positive legislation.

7 As one can see, although he does not preclude some role of government in the process, Menger believed that state regulation not generated money, but only "perfected and adjusted to the manifold and varying needs of an evolving commerce" (Menger, 1892 [2009], 52) or acknowledged "an item which had already become money notes" (Menger, 1883 [1985], 153). 


\section{Arkadiusz Sieroń}

8 Cf. Menger (1883 [1985], 154; 1892 [2009], 34).

9 Cf. Menger (1871 [2007], 261; 1883 [1985], 155).

10 O'Driscoll $(1985,16)$ points out that Mises also extended Menger's analysis to modern monetary systems by examining the possibility of government's making coins or notes money by 'fiat'."

11 Of course, Menger's contributions to monetary theory are definitely larger, but the limited space of the article makes it impossible to discuss them all. I would like only to add here that Menger showed that the primary functions of money is being a medium of exchange, while others functions attributed to it are merely secondary (Mises, 1912 [1953]). Moreover, Menger's focus on marketability preceded Keynesian emphasizing the importance of liquidity. Actually, for Menger, money is the most liquid of all goods. Hence contrary to Walras' approach treating money as numéraire - Menger considers money as non-neutral good, which exerts real effects on economic development. Last but not least, Menger's contribution also debunks the legal restrictions theory of the demand for money (O’Driscoll, 1985).

12 On Bitcoin, see: Sieroń (2017).

13 However, some researchers believe that the invisible-hand explanations of law are not appropriate, as following the law is not self-enforcing; i.e. it is possible to benefit at the expense of others by breaking the rules (Buchanan, 1975).

14 Boettke and Candela $(2014,124)$ see law as "the fifth factor of production, or more fundamentally as the institutional framework within which the production process takes place."

15 Cf. Benson (2011) who notices that attributes of a customary legal system include an emphasis on individual rights and private property, strong incentives to avoid violent forms of dispute resolution, restitution to victims instead of retribution, voluntary recognition of rules of obligation, and legal change arising through an evolutionary process of developing customs and norms.

16 Cf. Leoni (1991, 57, emphasis original): "nobody can tell whether a rule may be only one year or one month or one day old when it will be abrogated by a new rule. All these rules are precisely worded in written formulae that readers or interpreters cannot change at their will. Nevertheless, all of them may go as soon and as abruptly as they came. The result is that, if we leave out of the picture the ambiguities of the text, we are always 'certain' as far as the literal content of each rule is concerned at any given moment, but we are never certain that tomorrow we shall still have the rules we have today."

17 Cf. Leoni (1991, 22): "A legal system centered on legislation resembles in its turn as we have already noticed - a centralized economy in which all the relevant decisions are made by a handful of directors, whose knowledge of the whole situation is fatally limited and whose respect, if any, for the people's wishes is subject to that limitation." In correspondence with Hayek, Leoni elaborates on the similarities between law and market: "I think that the underlying idea of such a theory is that there is a market of the law as well as there is a market of goods. The rules correspond to the prices: they are the expression of the conditions requested for the exchange of actions and behaviours, just as the prices are the expression of certain conditions requested for the exchange of the goods. And the rules, as well as the prices are not imposed, but found out. I said before that the rules are found out by some special kind of people. But even this is true only partially. Everybody can find out a rule under given circumstances: this happens whenever people exchange their actions, their behaviours etc. at certain conditions without being compelled to consult anybody" (Masala 2003, 228, quoted in Boettke and Candela, 2014, 129-30). 
18 Another similarity to central planning is that legislation also entails unintended consequences.

19 More on Leoni's insights and contributions, see: Aranson (1988).

20 Nevertheless, Hayek (1998) was skeptical whether the legislation could be dispensed completely.

\section{R E F E R E N C E S}

Aranson P. H., 1988, "Bruno Leoni in Retrospect", Harvard Journal of Law \& Public Policy, XI, No. 3.

Barry N., 1982, "The Tradition of Spontaneous Order", Literature of Liberty. Vol. V, No. 2, Arlington, VA: Institute for Humane Studies, pp. 7-58.

Benson B. L., 1989, "The Spontaneous Evolution of Commercial Law", Southern Economic Journal, 55, pp. 644-61.

Benson B. L., 2011, The Enterprise of Law. Oakland, California: The Independent Institute.

Boettke P., 1990, "The Theory of Spontaneous Order and Cultural Evolution in the Social Theory of F.A. Hayek", Cultural Dynamics, Vol. 3, No. 1, pp. 61-83.

Boettke P., Candela R., 2014, "Hayek, Leoni, and Law as the Fifth Factor of Production," Atlantic Economic Journal, Vol. 42, No. 2, June, pp. 123-31.

Buchanan J. M., 1975, The limits of liberty: Between anarchy and Leviathan, Chicago: University of Chicago.

Hayek F., 1945, "The Use of Knowledge in Society," American Economic Review, Vol. 35, No. 4.

Hayek F., 1952, The Counter-Revolution of Science, Indianapolis: Liberty Classics.

Hayek F., 1969, "The Results of Human Action but not of Human Design," in Studies in Philosophy, Politics and Economics, New York: Simon and Schuster, Clarion Book, pp. 96-105.

Hayek F. 1976 [2007], Introduction, in: Menger C., 1871 [2007] Principles of Economics, Auburn, Ala.: Ludwig von Mises Institute.

Hayek F., 1998, Law, Legislation and Liberty, London: Routledge.

Higgs R., 1997, "Regime Uncertainty Why the Great Depression Lasted So Long and Why Prosperity Resumed after the War", The Independent Review, Vol. I, No. 4.

Horwitz S., 2001, "From Smith to Menger to Hayek", The Independent Review, Vol. VI, No. 1, Summer, pp. 81-97.

Huerta de Soto, J. (2006), Money, Bank Credit, and Economic Cycles, Auburn, Ala.: Ludwig von Mises Institute.

Jaffe W., 1976, "Menger, Jevons and Walras De-Homogenized", Economic Inquiry, No. XIV, December. 
Kinsella S. N., 1995, "Legislation and the Discovery of Law in a Free Society," Journal of Libertarian Studies, Vol. 11, No. 2, Summer, pp. 132-181.

Leoni B., 1991, Freedom and the Law, expanded 3 ed., Indianapolis: Liberty Fund, available at: http://oll.libertyfund.org/titles/920, accessed July 7, 2017, numbering according to the Ebook PDF version.

Machaj M., 2015, "Marginal Unit vs. Marginal Unit - Some Additional Thoughts on the Differences between Menger, Jevons, and Walras", Economia. Wroclaw Economic Review, Vol. 21, No. 4, pp. 9-16.

Masala A., 2003, Il liberalismo di Bruno Leoni, Milan: Il Sole 24 Ore.

Menger C., 1883 [1985], Investigations into the Method of the Social Sciences with Special Reference to Economics, New York and London: York University Press.

Menger C., 1871 [2007], Principles of Economics, Auburn, Ala.: Ludwig von Mises Institute.

Menger C., 1892 [2009], On the Origins of Money, Auburn, Ala.: Ludwig von Mises Institute.

Mises L. 1920 [1990], "Economic Calculation in the Socialist Commonwealth", Auburn, Ala.: Ludwig von Mises Institute.

Mises L., 1912 [1953], The Theory of Money and Credit, New Haven: Yale University Press.

Mises, L. (1949) [1998], Human Action: A Treatise on Economics, Scholar's Edition, Auburn, Ala.: Ludwig von Mises Institute.

O’Driscoll G. P. Jr., 1985, "Money: Menger's Evolutionary Theory", Research Paper, No. 8508, Federal Reserve Bank of Dallas.

Penchev D. P., 2014, "Carl Menger on the Theory of Economic History.Reflections from Bulgaria", Panoeconomicus, No. 6, pp. 723-738.

Salerno J. T., 2000, "Biography of Carl Menger: the Founder of the Austrian School (1840-1921)", Mises Institute, August 16, 2000, available at: https://mises. org/library/biography-carl-menger-founder-austrian-school-1840-1921, accessed July 1, 2017.

Selgin G., 1988, The Theory of Free Banking, Totowa: Rowman and Littlefield.

Simmel G., 2004, The Philosophy of Money, third ed., London and New York: Routledge.

Smith A., 1776 [1976], An Inquiry into the Nature and Causes of the Wealth of Nations, Chicago: University of Chicago Press.

Stringham E. P., Zywicki T. J., "Hayekian Anarchism", George Mason Law \& Economics Research Paper, No. 11-06.

White L., 1984, Free Banking in Britain, New York: Cambridge University Press.

Zywicki T., 2014, "Bruno Leoni's Legacy and Continued Relevance", Journal of Private Enterprise, Vol. 30, No. 1, pp. 131-141. 